\title{
Pengaruh Model Pembelajaran Guided Discovery dengan Pendekatan Kontekstual terhadap Hasil Belajar Kognitif
}

\author{
Yulisya Zuriatni ${ }^{1}$, Endang Budiasih ${ }^{1}$, Sumari $^{1}$ \\ ${ }^{1}$ Pendidikan Kimia-Universitas Negeri Malang
}

\begin{tabular}{l} 
INFO ARTIKEL \\
\hline Riwayat Artikel: \\
Diterima: 09-04-2019 \\
Disetujui: 22-06-2019 \\
\hline
\end{tabular}

\section{Kata kunci:}

guided discovery; contextual approach; cognitive learning outcomes; guided discovery; pendekatan kontekstual; hasil belajar kognitif

\begin{abstract}
ABSTRAK
Abstract: This study aims to determine the effect of guided discovery learning model with a contextual approach to cognitive learning outcomes. The research used was a quasi-experimental with pretest-posttest control group design. The research sample was taken from two $11^{\text {th }}$ year classes SMAN 7 Malang. The experimental class was taught using the guided discovery model of the contextual approach and the control class using a conventional model with a contextual approach. The hypothesis test used is the Independent T-Test. The results showed that the guided discovery model with a contextual approach had an effect on improving the cognitive learning outcomes of students with an average gain score of 0.7 with a very good category.
\end{abstract}

\begin{abstract}
Abstrak: Penelitian ini bertujuan untuk mengetahui pengaruh model pembelajaran guided discovery dengan pendekatan kontekstual terhadap hasil belajar kognitif. Penelitian yang digunakan yaitu eksperimen semu dengan pretest-posttest control group design. Sampel penelitian ini diambil dari dua kelas XI MIPA SMAN 7 Malang. Kelas eksperimen dibelajarkan menggunakan model guided discovery pendekatan kontekstual dan kelas kontrol menggunakan model konvensional dengan pendekatan kontekstual. Uji yang digunakan adalah Independent T-Test. Hasil penelitian menunjukkan bahwa model guided discovery dengan pendekatan kontekstual berpengaruh terhadap peningkatan hasil belajar kognitif peserta didik dengan hasil gain score rata-rata sebesar 0,7 dengan kategori tinggi.
\end{abstract}

\author{
Alamat Korespondensi: \\ Yulisya Zuriatni \\ Pendidikan Kimia \\ Universitas Negeri Malang \\ Jalan Semarang 5 Malang \\ E-mail: zyulisya@gmail.com
}

Kimia merupakan salah satu materi yang terdapat di Sekolah Menengah Atas. Dalam pejalaran kimia terdapat banyak pokok bahasan, salah satunya adalah laju reaksi. Laju reaksi merupakan salah satu kajian kimia yang sangat menuntut kajian aspek makroskopis, mikroskopis, dan simbolik (Sudria, Redhana, \& Samiasih, 2011) Aspek secara maksroskopis seperti pada peristiwa perkaratan pada pagar besi, proses pembakaran sate, dan proses pematangan buah dengan karbit. Aspek mikroskopis berupa proses kerja enzim dalam tubuh dan proses tumbukan yang dapat memengaruhi laju reaksi. Aspek simbolik berupa perhitungan yang menentukan kelajuan suatu reaksi kimia baik melalui tabel ataupun grafik.

Laju reaksi menurut Suryati (2011) memiliki kesulitan tersendiri bagi peserta didik, di antaranya peserta didik sulit memahami konsep lain yang mendasari konsep laju reaksi, seperti stoikiometri. Cakmakci (2010) mengutarakan bahwa kesulitan utama peserta didik salah satunya adalah membedakan antara laju reaksi dan waktu reaksi serta menghubungkan dan menggambarkan grafik keduanya sehingga menyebabkan hasil belajar peserta didik menjadi rendah. Kesulitan memahami konsep dapat dikurangi dengan memaksimalkan proses belajar peserta didik serta dapat merangsang pikiran, perhatian dan keterampilan peserta didik saat kegiatan belajar berlangsung. Namun, tidak hanya media pembelajaran saja, model pembelajaran dan teknik pembelajaran juga harus semakin berkembang untuk menarik minat belajar peserta didik (Putri \& Dwikoranto, 2017). Penggunaan model pembelajaran aktif seperti guided discovery akan membantu peserta didik memperoleh pengetahuannya sendiri sehingga mendorong peserta didik dalam memahami, menerapkan, dan mengembangkan pola pikirnya.

Guided discovery merupakan pembelajaran berbasis kontruktivis yang berbasis student centered sehingga peserta didik terlibat secara aktif dalam proses belajar mengajar, selain itu guru juga memfasilitasi dan membimbing peserta didik untuk belajar. Illahi (2012) berpandangan bahwa discovery learning merupakan salah satu metode yang memungkinkan para anak didik terlibat langsung dalam kegiatan belajar mengajar sehingga mampu menggunakan proses mentalnya untuk menemukan suatu konsep atau teori yang sedang dipelajari. Tahapan pembelajaran guided discovery meliputi stimulation (stimulasi), problem statement (penetapan masalah), data collecting (pengumpulan data), data processesing (pemrosesan data), verification (verifikasi) dan generalization (menyimpulkan). Hosnan (2014) menyatakan bahwa guided discovery memiliki peranan positif bagi peserta didik, di antaranya mendorong peserta didik berpikir dan bekerja atas inisiatifnya sendiri sehingga membantu daya ingat peserta didik 
atas konsep yang telah mereka bentuk. Solusi lain yang dapat dilakukan dalam meningkatkan hasil belajar ialah pendekatan kontekstual. Pendekatan kontekstual menurut Sanjaya (2008) adalah pendekatan yang menekankan suatu pembelajaran kepada proses keterlibatan secara utuh untuk dapat menemukan materi yang dipelajari dan mengaitkannya dengan situasi kehidupan sehari-hari sehingga peserta didik terdorong untuk menerapkannya dalam kehidupan mereka. Pendekatan kontekstual menuntut tiga hal, yaitu (1) interaksi antara peserta didik dengan guru, (2) interaksi antara peserta didik dengan teman sejawatnya, dan (3) peserta didik dengan sumber belajarnya sehingga pembelajaran yang dilakukan menjadi lebih bermakna dan memberikan pengalaman belajar yang menyenangkan. Berdasarkan uraian tersebut, penelitian ini bertujuan untuk mengetahui pengaruh model pembelajaran guided discovery dengan pendekatan kontekstual terhadap hasil belajar kognitif peserta didik.

\section{METODE}

Jenis penelitian ini adalah penelitian eksperimen. Desain penelitian yang digunakan adalah eksperimen semu jenis pretest-posttest control group design. Populasi dalam penelitian ini adalah seluruh peserta didik kelas XI MIPA SMAN 7 Malang yang terdiri dari enam kelas. Sampel ditentukan dengan cluster random sampling. Kelas eksperimen (N=32) dibelajarkan menggunakan model pembelajaran guided discovery dengan pendekatan kontekstual dan kelas kontrol $(\mathrm{N}=32)$ dibelajarkan menggunakan model pembelajaran konvensional dengan pendekatan kontekstual. Skema rancangan penelitian dapat dilihat pada tabel 1 .

Tabel 1. Rancangan Penelitian

\begin{tabular}{cccc}
\hline Kelompok & Pretest & Perlakuan & Posttest \\
\hline Eksperimen & $\mathrm{O}_{1}$ & $\mathrm{X}$ & $\mathrm{O}_{2}$ \\
Kontrol & $\mathrm{O}_{3}$ & - & $\mathrm{O}_{4}$ \\
\hline
\end{tabular}

Keterangan :

$\mathrm{O}_{1}-\mathrm{O}_{2}$ : Pencapaian skor prestest posttest kelas eksperimen

$\mathrm{O}_{3}-\mathrm{O}_{4}$ : Pencapaian skor pretest dan posttest kelas kontrol

$\mathrm{X} \quad$ : Pembelajaran dengan model guided discovery dengan pendekatan kontekstual

: pembelajaran dengan model konvensional dengan pendekatan kontekstual

Penelitian ini dilakukan selama 10 minggu sebanyak 10 kali pertemuan dengan alokasi waktu dua jam pelajaran sesuai dengan silabus yang ada. Variabel terikat penelitian ini adalah hasil belajar kognitif peserta didik dan variabel bebasnya adalah model pembelajaran yang digunakan. Penelitian diawali dengan melakukan kajian materi dan kajian literatur terkait penelitian, kemudian dilanjutkan dengan menyusun perangkat, seperti RPP, LKS, dan instrumen pengukuran. Instrumen pengukuran hasil belajar kognitif berjumlah 15 soal. Hasil tes kemudian dianalisis menggunakan Independent T-Test untuk melihat apakah tujuan penelitian ini dapat tercapai.

\section{HASIL}

Data hasil belajar kognitif peserta didik diperoleh dari hasil pretest dan posttest. Pretest dilakukan sebelum peserta didik mendapatkan perlakuan pada materi laju reaksi. Data hasil pretest peserta didik kelas eksperimen dan kelas kontrol dapat dilihat pada gambar 1.

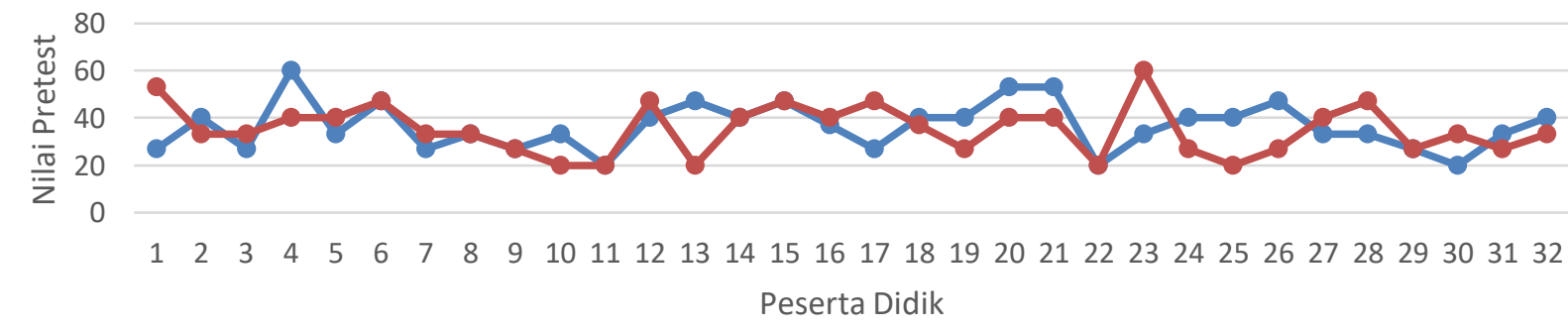

Kelas Eksperimen $\quad$ Kelas Kontrol

Gambar 1. Nilai Pretest Peserta Didik Kelas Eksperimen dan Kelas Kontrol

Setelah diterapkan perlakuan dilakukan posttest untuk melihat kenaikan hasil belajar kognitif peserta didik. Data hasil posttest peserta didik kelas eksperimen dan kelas kontrol dapat dilihat pada gambar 2. Data hasil pretest dan posttest hasil belajar kognitif pada materi laju reaksi dapat dilihat pada tabel 2. 


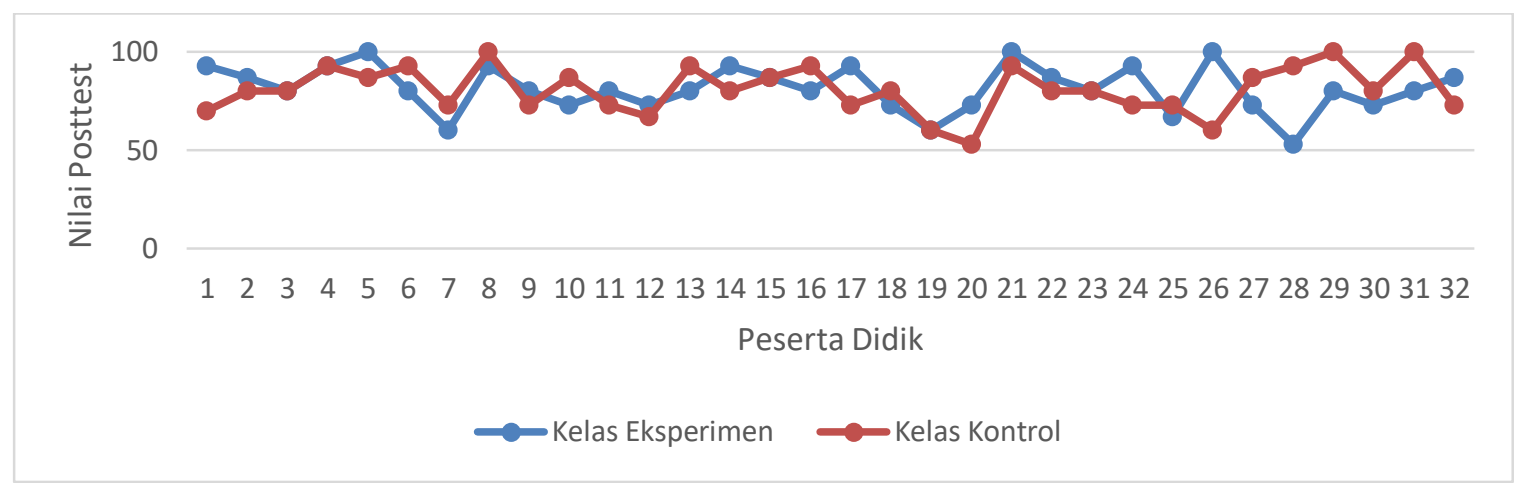

Gambar 2. Nilai Posttest Peserta Didik Kelas Eksperimen dan Kelas Kontrol

Tabel 2. Rekapitulasi Nilai Pretest dan Posttest Hasil Belajar Kognitif Peserta Didik

\begin{tabular}{cccccc}
\hline \multirow{2}{*}{ Kelas } & \multirow{2}{*}{ Jumlah Peserta Didik } & \multicolumn{2}{c}{ Pretest } & \multicolumn{2}{c}{ Posttest } \\
\cline { 3 - 6 } & & M & SD & M & SD \\
\hline Eksperimen & 32 & 36,375 & 9,967 & 81,375 & 11,834 \\
\hline Kontrol & 32 & 35,156 & 10,442 & 80,843 & 12,086 \\
\hline
\end{tabular}

Tabel 2 menunjukkan bahwa terdapat peningkatan nilai rata-rata tes dari pretest ke posttest hasil belajar kognitif peserta didik pada kelas eksperimen dan kelas kontrol. Kenaikan nilai rata-rata kelas eksperimen dan kelas kontrol masing-masing sebesar 45,00 dan 45,67. Meskipun terjadi kenaikan nilai rata-rata pada kedua kelas, namun kenaikan rata-rata tes kelas kontrol lebih tinggi daripada kelas eksperimen setelah dilaksanakan pembelajaran. Meskipun demikian, jumlah peserta didik yang memperoleh nilai diatas Kriteria Ketuntasan Minimal pada kelas eksperimen (23 orang) lebih banyak daripada kelas kontrol (20 orang).

Sebelum dilakukan uji hipotesis terhadap nilai hasil belajar kognitif peserta didik, terlebih dahulu dilakukan uji prasyarat analisis yaitu uji normalitas dan uji homogenitas. Berdasarkan uji prasyarat yang dilakukan, diketahui bahwa nilai pretest dan posttest hasil belajar kognitif peserta didik pada kedua kelas normal dan memiliki varian yang sama (homogen). Hasil pengujian hipotesis yang dilakukan dapat dilihat pada tabel 3.

Tabel 3. Hasil Uji t Hasil Belajar Kognitif

\begin{tabular}{cccccc}
\hline & M & SE & t & df & Sig(2-tailed) \\
\hline Hasil Belajar Kognitif & 0,531 & 2,990 & 0,178 & 62 & 0,860 \\
\hline
\end{tabular}

Berdasarkan hasil uji Independent T-test pada tabel 3, diketahui nilai probabilitas signifikansi untuk model pembelajaran pada hasil belajar kognitif materi laju reaksi sebesar 0,860 (sig>0,05) sehingga pernyataan $\mathrm{H}_{\mathrm{o}}$ diterima dan $\mathrm{H}_{1}$ ditolak. Hal ini berarti tidak ada perbedaan yang signifikan pada hasil belajar kognitif materi laju reaksi antara peserta didik yang dibelajarkan dengan menggunakan model pembelajaran guided discovery dengan pendekatan kontekstual dengan peserta didik yang dibelajarkan dengan menggunakan model pembelajaran konvensional dengan pendekatan kontekstual.

Nilai pretest dan posttest hasil belajar kognitif pada kelas eksperimen dan kelas kontrol masing-masing dihitung dengan $N$-Gain. Uji gain ternormalisasi ( $N$-Gain) dilakukan untuk mengetahui peningkatan hasil belajar kognitif peserta didik setelah diberikan perlakuan. Peningkatan ini diambil dari nilai pretest dan posttest yang didapatkan peserta didik. Hasil analisis N-Gain kelas eksperimen disajikan pada gambar 3.

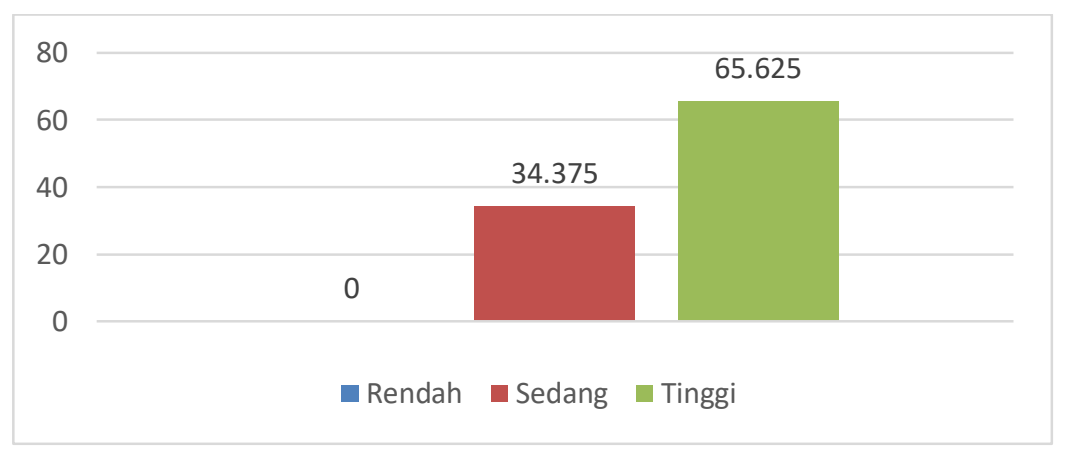

Gambar 3. N-Gain Hasil Belajar Kognitif Kelas Eksperimen 
Berdasarkan gambar 3 diketahui dari 32 orang peserta didik kelas eksperimen tidak ada peserta didik yang memperoleh $\mathrm{N}$-gain kategori rendah, 11 orang peserta didik berada pada kategori sedang (34,375\%) dan 21 orang berada pada kategori tinggi $(65,625 \%)$. Hasil analisis N-Gain kelas kontrol dapat dilihat pada gambar 4.

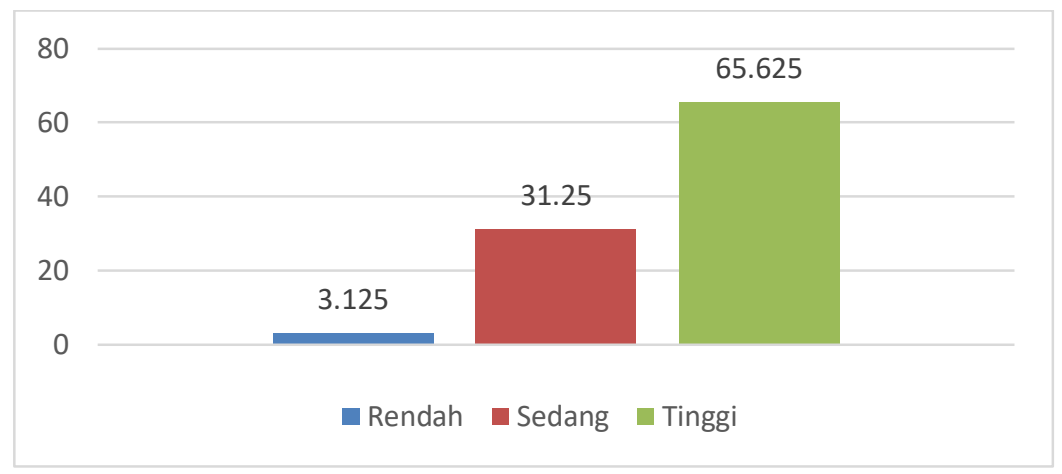

Gambar 4. N-Gain Hasil Belajar Kognitif Kelas Kontrol

Berdasarkan gambar 4 dapat disimpulkan bahwa terdapat satu orang peserta didik yang memiliki N-Gain dengan kategori rendah $(3,125 \%), 10$ orang pada kategori sedang $(31,25 \%)$, dan 21 orang pada kategori tinggi $(65,625 \%)$. Berdasarkan gambar 1 dan 2 perbedaan nilai $\mathrm{N}$-Gain kedua kelas sangat kecil sehingga hal ini menyebabkan hasil perhitungan rata-rata $N$-Gain pada kelas eksperimen dan kontrol masing-masing tidak jauh berbeda, yaitu sebesar 0,7. Hal ini berarti peningkatan nilai pretest dan posttest kelas eksperimen dan kelas kontrol berada pada kategori tinggi.

\section{PEMBAHASAN}

Proses pembelajaran yang berlangsung pada kelas eksperimen dan kelas kontrol berlangsung dengan baik. Pada setiap kegiatan pembelajaran disajikan suatu fenomena yang dapat membantu proses berpikir peserta didik. Selain itu, setiap peserta didik diberi kesempatan untuk berbicara dan mengutarakan pendapat mengenai permasalahan yang disajikan, mendengarkan pendapat peserta didik lain secara cermat, dan bekerjasama untuk membangun pengetahuan dengan teman sekelompoknya. Peningkatan hasil belajar pada kedua kelas dapat dikarenakan beberapa hal berikut. Pertama, penggunaan lembar kerja yang memiliki beberapa manfaat (a) penyajian materi yang lebih jelas, (b) mengatasi keterbatasan waktu untuk bertatap muka bagi guru maupun peserta didik, (c) memfasilitasi peserta didik agar belajar mandiri, dan (d) memungkinkan peserta didik untuk melakukan latihan soal. Selain itu, menurut teori aliran belajar behavioristik yang dijelaskan oleh Thorndike pada Law of exercise menyatakan bahwa jika sesuatu materi semakin sering dilakukan latihan-latihan maka asosiasi tersebut semakin kuat. Hal ini berkaitan dengan lembar kerja pada penelitian ini yang menyediakan sarana berlatih bagi peserta didik berupa soal-soal latihan. Kedua, penggunaan model pembelajaran yang memiliki manfaat (a) membuat materi abstrak menjadi lebih konkret, (b) mengakrabkan peserta didik dengan konsep yang asing, (c) membantu peserta didik memahami konsep yang sulit dipahami, (d) meningkatkan minat peserta didik terhadap materi ajar.

Peningkatan hasil belajar kognitif terjadi pada kedua kelas, meskipun demikian rata-rata hasil belajar kognitif kelas eksperimen lebih tinggi daripada kelas kontrol. Hal ini disebabkan oleh adanya pengaruh dari model pembelajaran yang digunakan. Pada kelas eksperimen peserta didik dibelajarkan menggunakan model pembelajaran guided discovery dengan pendekatan kontekstual yang memiliki dampak positif terhadap peningkatan hasil belajar peserta didik. Hal ini sesuai dengan penelitian Martaida, dkk (2017) bahwa kegiatan pembelajaran penemuan dapat memberikan kesempatan bagi peserta didik untuk menemukan sesuatu melalui percobaan. Ketika peserta didik dalam kegiatan ilmiah (percobaan), peserta didik dilatih untuk menjadi terampil memperoleh dan memproses informasi melalui kegiatan berpikir dengan mengikuti prosedur ilmiah, seperti, terampil dalam mengamati, mengukur, mengklasifikasikan, menarik kesimpulan, dan mengomunikasikan temuan. Sejalan dengan penelitian oleh Delen dan Kesercioglu (2012) bahwa mempelajari proses pengetahuan ilmiah adalah kemampuan yang sangat penting bagi peserta didik. Berikut disajikan grafik perbandingan persentase perolehan hasil belajar kognitif peserta didik pada kedua kelas. 


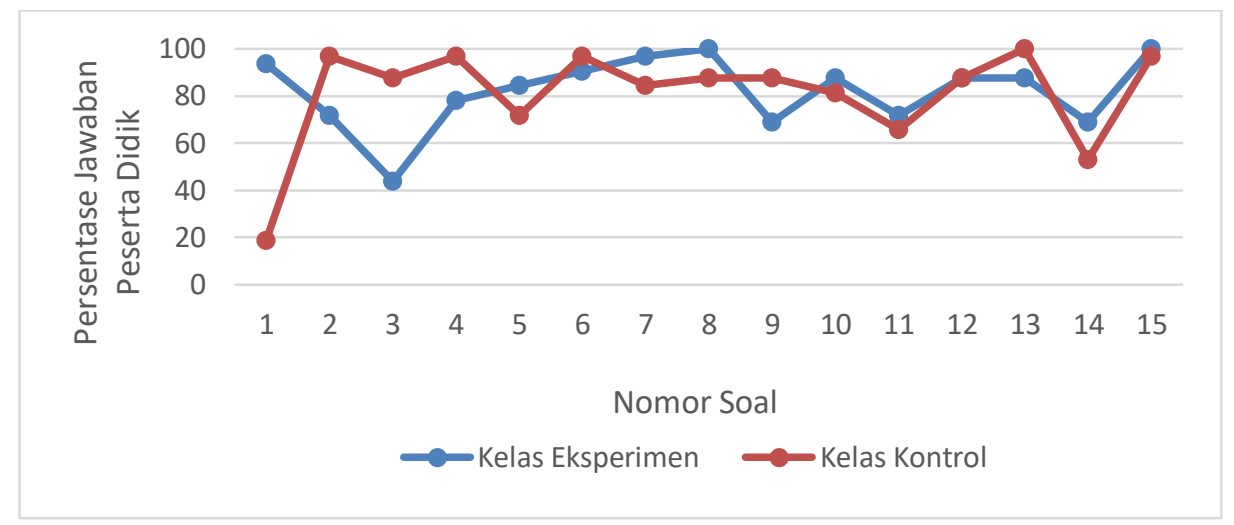

\section{Gambar 5. Persentase Hasil Belajar Kognitif Kelas Eksperimen dan Kelas Kontrol}

Berdasarkan gambar 5, terlihat bahwa persentase perolehan hasil belajar kognitif pada kedua kelas relatif sama kecuali pada nomor 1 dan 3 yang memiliki perbedaan yang sangat signifikan. Hal ini membuktikan bahwa peserta didik kelas eksperimen memiliki pemahaman yang baik mengenai konsep laju reaksi. Hal ini sejalan dengan penelitian Jannah, dkk (2018) yang menyatakan bahwa penerapan model guided discovery learning pada materi konsep mol membuat peserta didik semakin aktif pada saat pembelajaran berlangsung sehingga sebagian besar peserta didik tuntas pada materi tersebut dan memberikan tanggapan yang baik terhadap penerapan model guided discovery. Ariyani (2017) lebih lanjut juga membuktikan bahwa dengan model pembelajaran guided discovery persentase rata-rata keterampilan proses sains peserta didik meningkat dan berpengaruh signifikan terhadap hasil belajar peserta didik.

Tahapan-tahapan pada model guided discovery membantu peserta didik menumbuhkembangkan proses berpikir dan mengonstruk pengetahuannya sehingga pembelajaran menjadi bermakna dan menghasilkan hasil belajar yang baik pula. Selain itu, pengombinasian antara model pembelajaran dengan pendekatan kontekstual juga memengaruhi hasil belajar kognitif tersebut. Hai-Jew (dalam Septianu \& Widyatmoko, 2012) discovery memberi ruang belajar peserta didik untuk membuat keputusan dan membentuk kompetensi belajar baru. Proses penemuan dalam pembelajaran guided discovery dapat menimbulkan terjadinya interaksi antara peserta didik dengan peserta didik, peserta didik dengan bahan ajar, peserta didik dengan guru, serta peserta didik dengan bahan ajar dan guru. Interaksi dapat pula terjadi antara peserta didik dalam kelompok kecil maupun kelompok besar.

Pada kelas kontrol digunakan model pembelajaran konvensional dengan pendekatan kontekstual yang menyebabkan peserta didik kelas kontrol lebih menguasai pemahaman yang dikaitkan dengan kehidupan nyata seperti faktor-faktor yang memengaruhi laju reaksi dibandingkan kelas eksperimen meskipun perbedaannya tidak terlalu signifikan. Penerapan pendekatan kontekstual memberikan motivasi belajar bagi peserta didik, baik untuk lebih bebas mengutarakan pendapatnya, bahkan memperoleh solusi pada pemikiran-pemikiran yang belum terjawab pada pikiran peserta didik melalui tukar pendapat dengan teman-teman sekelompoknya. Pembelajaran dengan teman sekelompok juga membuat peserta didik lebih semangat dalam belajar serta bekerja sama, sehingga menjadikan peserta didik saling berkomunikasi, berdiskusi, berbagi, dan berinteraksi satu sama lain untuk mewujudkan tujuan bersama. Hal inilah yang perlu diperhatikan agar pemahaman dan pengetahuan peserta didik pada materi dapat terus ditingkatkan dengan baik dan tertanam dalam diri peserta didik. Selain itu, informasi-informasi berdasarkan pengalaman peserta didik berupa pengungkapan ide-ide dan pemikiran pada forum diskusi menimbulkan keberanian dan keterbukaan pikiran-pikiran peserta didik untuk lebih mudah dikembangkan berdasarkan pada pokok materi yang diajarkan. Hasil penelitian sejalan dengan dengan Adi, Mestawaty, \& Minarni (2016) yang menyatakan bahwa pendekatan kontekstual mampu meningkatkan hasil belajar peserta didik serta membangkitkan keaktifan peserta didik dalam belajar sehingga ketika dikombinasikan dengan model pembelajaran konvensional hasil belajar kognitif peserta didik meningkat dan tidak terdapat perbedaan yang signifikan dibandingkan model pembelajaran guided discovery.

Pada penelitian ini, pembelajaran kimia pada kelas eksperimen digunakan model pembelajaran guided discovery dan kelas kontrol menggunakan model pembelajaran konvensional, namun kedua kelas diajarkan dengan bantuan pendekatan yang sama, yaitu pendekatan kontekstual. Pendekatan kontekstual menekankan pada keterkaitan materi yang dipelajari dengan situasi kehidupan nyata peserta didik sehingga dapat mengetahui penerapan setiap materi hasil belajar peserta didik dalam kehidupan sehari-hari, baik di lingkungan keluarga, sekolah, maupun masyarakat. Aktivitas belajar peserta didik selama proses pembelajaran menyebabkan proses pembelajaran berlangsung secara alamiah dalam bentuk kegiatan peserta didik bekerja dan mengalami, bukan mentransfer pengetahuan dari guru ke peserta didik. Selain itu, peserta didik juga aktif mengemukakan pendapat dan berpikir kritis untuk menemukan suatu kesimpulan atau jawaban sehingga terjadi peningkatan pemahaman, bukan menghafal. Proses pembelajaran yang menyenangkan juga menambah motivasi peserta didik dalam mengikuti pembelajaran (Putranto \& Susatyo 2013). 


\section{SIMPULAN}

Berdasarkan hasil penelitian dan analisis data dapat disimpulkan bahwa tidak terdapat perbedaan hasil belajar kognitif antara peserta didik yang dibelajarkan menggunakan model pembelajaran guided discovery dengan pendekatan kontekstual dan peserta didik yang dibelajarkan menggunakan model pembelajaran konvensional dengan pendekatan kontekstual. Kedua model pembelajaran efektif dalam meningkatkan hasil belajar kognitif peserta didik. Secara klasikal, ketuntasan peserta didik kelas eksperimen sebesar 71,875\% dan kelas kontrol sebesar 62,5\% dengan peningkatan hasil belajar kognitif peserta didik sebesar 0,70 yang termasuk dalam kategori tinggi. Peralihan proses pembelajaran dari konvensional menjadi konstruktivistik melalui pendekatan kontekstual reflektif membutuhkan waktu bagi peserta didik untuk menyesuaikan diri. Oleh karena itu, sebelum dilakukan pengambilan data sebaiknya dilakukan pembelajaran serupa untuk membiasakan bagi peserta didik dengan model pembelajaran serupa.

\section{DAFTAR RUJUKAN}

Adi., Mestawaty., \& Minarni. (2016). Penerapan Pendekatan Kontekstual untuk Meningkatkan Hasil Belajar Peserta didik pada Mata Pelajaran IPA Kelas III Madrasah Ibtidaiyah Al-Hikmah Tolitoli. Jurnal Kreatif Tadulako Online, 4(10), 115125.

Ariyani, R. D., \& Mahardika, I. K. (2017). Model Pembelajaran Guided Discovery (GD) disertai Media Audiovisual dalam Pembelajaran IPA (Fisika) di SMP. Jurnal Pembelajaran Fisika, 6(4), 397-403.

Cakmakci, G. (2010). Identifying Alternative Conceptions of Chemical Kinetics among Secondary School and Undergraduate Students in Turkey. Journal of Chemical Education, 87(4), 449-455. https://doi.org/10.1021/ed8001336

Creswell, J. W. (2012). Research Design Pendekatan Kualitatif, Kuantitatif, dan Mixed. Yogyakarta: Pustaka Belajar.

Delen, İ., \& Kesercioğlu, T. (2012). How Middle School Students' Science Process Skills Affected by Turkey's National Curriculum Change? Journal of Turkish Science Education, 9(4), 8.

Hosnan. (2014). Pendekatan Saintifik dan Kontekstual Dalam Pembelajaran Abad 21. Bogor: Ghalia Indonesia.

Illahi, M. T. (2012). Pembelajaran Discovery Strategi \& Mental Vacational Skill. Yogyakarta: Diva Press.

Jannah, D. M., Hasan, M., \& Fitri, Z. (2018). Penerapan Model Guided Discovery Learning pada Materi Konsep Mol Kelas X di SMAN 9 Banda Aceh. 3(3), 6.

Martaida, T., Bukit, N., \& Ginting, E. M. (2017). The Effect of Discovery Learning Model on Student's Critical Thinking and Cognitive Ability in Junior High School. Journal of Research \& Method in Education, 7(6), 8.

Putranto, T. A., Susatyo, E. B., \& Siadi, K. (2013). Pencapaian Ketuntasan Hasil Belajar dengan Model Snowballing Pendekatan Contextual Teaching and Learning. Chemistry in Education, 2(1).

Putri, D. K., \& Dwikoranto. (2017). Penerapan Model Pembelajaran Guided Discovery untuk Meningkatkan Hasil Belajar Siswa pada Materi Hukum Newton di Kelas X SMA Negeri 1 Lamongan. Jurnal Inovasi Pendidikan Fisika, 6(3), 161166.

Sanjaya, W. (2008). Strategi Pembelajaran Beorientasi Standar Proses Pendidikan. Jakarta: Kencana.

Septianu, E., \& Widiyatmoko, A. (2014). Pengembangan Modul IPA Terpadu Tema Perubahan Zat Berbasis Discovery untuk Meningkatkan Keterampilan Generik dan Hasil Belajar Siswa. Unnes Science Education Journal, $3(3), 9$.

Sudria, I. B. N., Redhana, I. W., \& Samiasih, L. (2011). Pengaruh Pembelajaran Interaktif Laju Reaksi Berbantuan Komputer terhadap Hasil Belajar Peserta didik Kelas XI SMAN 2 Singaraja. Jurnal Pendidikan dan Pengajaran, 44(1), $25-33$.

Suryati. (2011). Pengaruh Model Pembelajaran Learning Cycle dipadukan dengan Diagram Alir terhadap Kualitas Proses, Hasil Belajar, dan Kemampuan Metakognitif Kimia Peserta didik Kelas XI SMA Negeri Malang. Skripsi tidak diterbikan. Universitas Negeri Malang, Malang. 